\title{
FISCAL STABILITY IN POLITICAL DISCOURSE: THE ROMANIAN CASE
}

\author{
Radu SIMANDAN 1
}

DOI: 10.1515/tjeb-2017-0007

\begin{abstract}
This article investigates the political resistance to fiscal stability institutions in Romanian context, as revealed in political discourse. To ascertain the a priori political predisposition against the fiscal stability framework, the theoretical findings of the public choice school of economics are utilized. Insights from the political discourse analysis body of literature are employed to the study of discourse against established fiscal stability institutions. Since the consensus arising from this literature is that politics is both acting and talking, the unit of analysis in our examination is the statement that can be classified as political discourse. After briefly analyzing the broader institutional context that provides the background for political discourse, the main storylines against fiscal stability recently emerged are reviewed. Seeking to determine the traits of the dominant political discourse against fiscal stability displayed by Romanian politicians in recent years, a quantitative assessment of the usage of these storylines is given. We find that publicly expressed disagreement with established fiscal stability institutions from the part of politicians and high-ranking bureaucrats has drastically increased over the analyzed period. The research has also revealed that the most employed storyline has been the one that belittles the significance of fiscal stability if the state uses the fiscal revenues for investing in transport infrastructure.
\end{abstract}

\section{Keywords: $\quad$ Fiscal policy, fiscal stability, political discourse analysis, Romania \\ JEL Classification: E62, H30}

${ }^{1}$ Assistant Lecturer PhD, University POLITEHNICA of Bucharest, Romania. 


\section{Introduction}

Not all institutional arrangements of man are created equal. Setting boundaries for the political game, different institutions lead to different political behavior. It has been a long tradition to consider the constitutional arrangements of a community (as the prime legal institution within which individuals act) as means to attain the production of public goods through collective action (Buchanan and Tullock, 1962). The community hires politicians and entrust them with power to conduct the production of public goods. As taxing is the only efficient way to finance the production of public goods, the power to tax is a key feature of the political power. However, along with this arrangement comes the danger that politicians abuse their power delegated to them by the community. Therefore, democracy entails the cost of power abuse and a constitutional way to deal with this cost (Gunning, 2003: 94).

A rational tendency of politicians in a democracy has been identified: they will use all the legal means they have in order to win the next elections (Gwartney et al., 2009: 129). The pursuit of votes shapes political action. In the present-day political system, politicians are rewarded for spending and are not penalized for creating large deficits and public debt. They tend to favor policies that provide visible current benefits and bear future costs that are difficult to identify, while at the same time, tend to oppose policies that entail immediate and evident costs (such as higher taxes) but yield future benefits that are complex and difficult to identify (the so-called shortsightedness effect). A common result of this effect is the attractiveness of debt financing of public spending. The holders of this perspective point to the fact that after the Second World War, and especially after 1960, the annual budgets of most developed countries have been in deficit rather than in surplus (Ibid.). Fiscal instability seems to be the natural outcome of an unrestricted democracy.

Moreover, fiscal instability is specific to unrestricted democracies, rather than permanent high levels of government deficit and debt - or, put differently, large deficits and debt are unsustainable. As Sargent and Wallace (1981) have demonstrated, along with large debt come an increased perceived risk of default and, consequently, an increased interest rate on long-term government bonds. A critical point is reached where the government can no longer borrow because the interest it has to pay is larger than the amount it tries to borrow. From this point, the government has no other solution than to restructure its budget by drastically cutting expenditures and increasing tax revenue. A vicious dynamic that leads to fiscal and macroeconomic instability is set in motion in an unconstrained political environment.

A constraining set of rules has been put forward as a means to deal with the fiscal problems that an unrestricted democracy generates. Developed by Brennan and Buchanan from the

\section{DE GRUYTER OPEN}

Timisoara Journal of Economics and Business | ISSN: 2286-0991 | www.tjeb.ro Year 2017 | Volume 10 | Issue 1 | Pages: 104-119 
Simandan, R. (2017).

early works of Knut Wicksell, this fiscal constitution perspective on limiting the taxing power of the state maintains that a coherent framework of fiscal rules - similar to constitutional political rules - is susceptible to be successful in limiting political discretion in this sphere and to create the stability needed for long-term growth (Brennan and Buchanan, 1980). As the authors writing in this tradition maintain, electoral constrains alone proved to be inefficient in promoting sound public finances and an enforceable set of rules is needed to constrain the power of government. The informal fiscal constitution that existed prior to the Keynesian moment could thus be restored (Buchanan and Wagner, 1977).

How do politicians accommodate such an environment that is specifically designed to limit their discretionary power in the fiscal sphere? Given the structure of incentives sketched above, some degree of resistance to the agreed-upon fiscal stability institutions is to be expected. Further, the existence of fiscal stability institutions introduces an additional incentive: if due to some special circumstances the common fiscal rules did not apply to the current government, large political benefits for the politicians in power would be expected. Hence, an incentive to circumvent the rules emerges, simultaneously with the motivation to be openly in favor of maintaining those rules.

The political positioning on any institution can be analyzed by studying both actual policies (e.g., constitutions, laws, regulations, etc.) and political discourse. Before becoming a reality, an institutional framework is debated and shaped in the political arena. Once in place, this framework is continuously debated and reshaped in a continuous process. Similarly, resisting a given institution requires both action and discursive practice. We argue that the investigation of political resistance to an institution requires the study of discursive practice against that institution.

In opposition to the traditional methodology of policy studies, Political Discourse Analysis (henceforth PDA) proposes an alternative approach to the study of social issues. Building on a"postempiricist" philosophy of science that seeks to depart from the objectivist conception of reality, the adherents to this current point out to the fact that politics and policy studies are understood through socially determined meanings (Fischer, 2003: 11). Discourses create and control systems of shared social meanings. The political reality under scrutiny is thought to be the result of a network of social meanings perpetuated through discourse. It follows that a postempiricist policy analyst investigates the role discourse plays in the reproduction of tacit political assumptions. For instance, in discourses about fiscal stability, a tacit or overt political assumption may be that fiscal stability excessively constrains the use of some policy tools and that the costs of maintaining it exceed the benefits.

Undoubtedly, the broader context required for fiscal stability institutions to be put in place must meet a variety of criteria in order to be successful. Because of the behavior of

\section{DE GRUYTER} OPEN
Timisoara Journal of Economics and Business | ISSN: 2286-0991 | www.tjeb.ro Year 2017 | Volume 10 | Issue 1 | Pages: 104-119 
Simandan, R. (2017).

politicians, discourse included, this institutional environment is further reshaped, with new institutions being devised and enacted. Certainly, a discursive practice in favor of institutions of fiscal stability develops and becomes embedded in the practices of these institutions. However, setting aside the social and political circumstances that make it possible for a specific institution to come into being, this article deals with the problem of the expected discursive practice of politicians once certain fiscal institutions are in place.

Put shortly, a specific dynamic can be identified that connects some basic features of contemporary democracy to a discursive practice against established fiscal stability institutions. This dynamic is schematically represented in Figure 1. Recognizing the fact that a particular type of discursive practice is likely to appear in a present-day democracy leads us to argue in favor of using the insights from the Political Discourse Analysis body of literature as analytical instruments in the investigation of this reality.

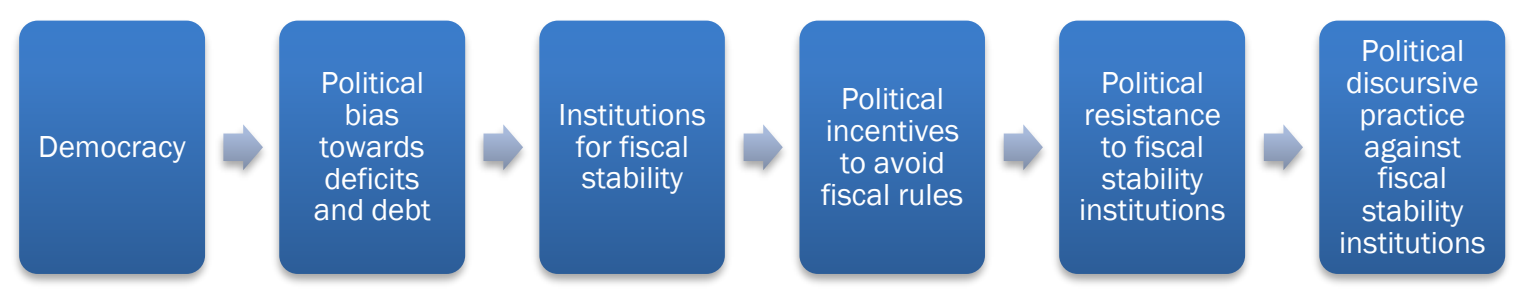

Figure 1. Sources of political discursive practice against fiscal stability institutions

Source: own

\section{Establishing the context: the institutional environment for fiscal stability}

Institutions have traditionally been analyzed disconnected from the discursive reality they entail (Phillips et al., 2004). Likewise, only in the late 1970s and the early 1980s, discourse structures began to be systematically studied in their social, historical and cultural contexts (van Dijk, 2008: 7). We shall regard the institutional environment for fiscal stability as the context in which political discourse related to fiscal stability occurs.

Like other types of social interaction, political discourse takes place in a specific context. Discourse both influence and is influenced by the factual social situation in which they occur. Used in this sense - which has been the traditional sense employed in the social sciences the context is a set of objective conditions that constitute the background to discursive practice. However, the definition of context that can be found in the discourse analysis body of literature rejects the objective nature of this reality and stresses the importance of the

\section{DE GRUYTER OPEN}

Timisoara Journal of Economics and Business | ISSN: 2286-0991 | www.tjeb.ro Year 2017 | Volume 10 | Issue 1 | Pages: 104-119 
Simandan, R. (2017).

subjective views of participants. From this standpoint, contexts are "(inter)subjective constructs designed and ongoingly updated in interaction by participants as members of groups and communities" (van Dijk, 2008: $x$ ). After all, "[i]f contexts were objective social conditions or constraints, all people in the same social situation would speak in the same way" (Ibid.). The environment in which a specific word is used has decisive implications for the meaning of that word. Factors outside the text under scrutiny must be taken into account for the description of the reality that the text aims to depict.

In this section, we shall briefly outline the main features of the broad (objective) institutional environment in which the examined political discourse occurred. After a succinct scrutiny of the (subjective) notion of fiscal stability, we shall concisely examine the main provisions of the legal act for fiscal stability (namely, the Fiscal Responsibility Law) and the organization that oversees the enactment of a responsible fiscal policy (namely, the Fiscal Council).

Fiscal stability is not easy to define. One sense of this phrase is the one that awards greater fiscal stability to an environment that has the least number of changes. Therefore, stability is synonymous with the lack of intentional fiscal change. For instance, this is the sense used by Institute for Research on Economic and Fiscal Issues in its yearly report Taxation in Europe (IREF, 2012). The problem with this use of the phrase is that desirable actions such as the reduction of tax rates may be deemed as fiscal instability. Another sense is defined in the legal act of fiscal responsibility. In this sense, the principle of stability insures that "the Government has the obligation to conduct the fiscal policy as to insure its predictability on the medium term, with the aim of maintain macroeconomic stability" - art. 4 (Law, 2010: 2). In this conception, fiscal stability is analogous with predictability. The problem with this connotation is that not all predictable (i.e., announced beforehand) fiscal actions promote long-run stability. Adding to these problems are the subjective nature of discourse (political discourse included) and the ensuing reconstruction of reality through discourse.

Fiscal stability is promoted through a number of institutions. The most widely used definition of institutions is the one advanced by Douglass North. In his conception, institutions are "rules of the game in a society, or more formally, are the humanly devised constraints that shape human interaction" (North, 1990: 3). Formal (or explicit) institutions include written rules such as laws and constitutions, while informal institutions are comprised of conventions and other cultural traditions. Both formal and informal rules function as coordination devices; they modify the expected costs and benefits of a particular action and thus alter human behavior. Therefore, the focal point of the analysis of institutions as rules is the study of regularity and predictability of human behavior. Both formal and informal institutions provide the background for discursive practice of politicians and they influence the behavior of politicians via the alteration of incentives and constraints that they face.

\section{DE GRUYTER OPEN}


Simandan, R. (2017).

Fiscal stability in political discourse: the Romanian case

Forming a background for human action, institutions must use linguistic tools. Adopting a discursive perspective to the study of institutions, Phillips et al. (2004: 638) show that institutions work through the production and dissemination of texts, rather than directly through action. Observing and interpreting action require the production of texts to mediate the relation between action and discourse. Taking this path allows the employment of the insights from the PDA body of literature to the study of real-life institutions. Similarly, we shall argue that the institutional environment for fiscal stability may also be successfully investigated using a discursive perspective.

A number of reasons behind the bias towards deficits and debt in democracies have been identified and analyzed. Among these, of utmost importance are information problems, the tendency to exploit future generations and the electoral competition (Calmfors, 2011: 13). Due to information problems, politicians may overrate future revenues from taxation as well as their ability to influence the rate of real GDP growth. Due to the tendency to exploit future generations, politicians are encouraged to spend without raising taxes so the future generations will have to pay more in taxes. Due to the electoral competition, governments are encouraged to spend today and to receive the benefits of spending, while the costs will probably be borne by a competing party tomorrow. All these facts also explain the pro-cyclical nature of fiscal policy that has been observed in practice.

Because of this structure of incentives for participants to the political process, a framework of legal institutions and organizations for fiscal stability has been put in place in virtually all advanced economies. The main goal of the legal institutions is to institute a set of mandatory fiscal rules that constrain political discretion in fiscal matters and alleviate the deficit and debt bias. Watchdog organizations in the form of fiscal councils have been established to oversee the application of the law. In particular, fiscal councils have been required to elaborate economic and fiscal forecasts (or to assess the forecasts developed by other agencies) and to gauge the impact of current fiscal actions on future generations.

The Romanian case closely follows the political and institutional logic described above. The Fiscal Responsibility Law (henceforth FRL) is the legal background for the institutional environment of fiscal stability in Romania. Enacted in March 2010, the main aim of this law was to strengthen the medium and long-term fiscal discipline. Its major elements are the three-year medium-term budget framework, the nominal government expenditure ceilings (its growth being limited to nominal GDP growth), limitations on supplementary budgets (to two per year, the first budget revision being submitted no earlier than July of each year), and the introduction of half-yearly and annual reports on economic and budget outlook. Moreover, it lays down a multiannual fiscal framework (Law, 2010). Because of the provisions of this law, it may be argued that the budget process has become more stable, predictable, and transparent.

DE GRUYTER OPEN 
Simandan, R. (2017).

An implication of the FSL has been the creation of the first independent monitoring and advising organism in the sphere of public finances - the Fiscal Council (henceforth FC). The main functions of the FC are to monitor the performance of fiscal policy conducted by the Government by verifying the conformity of fiscal decisions with legal fiscal rules, to offer advice to the Government on any fiscal matter by making public its opinions and recommendations, and to analyze the stance of the country's fiscal policy. To insure its political independence, the members of the FC are appointed by civil-society organizations, like the leading university of economics and academy of sciences. The FC establishes its own annual budget, internal rules and organizational chart. The FC must issue an opinion on the annual draft budget law, while the Government is required to send to the FC all the necessary documentation and officially ask for FC's opinion.

In short, the behavior of politicians pertaining to fiscal issues is constrained by a legal framework that contains detailed fiscal rules and limitations and establishes an autonomous fiscal watchdog organization to insure compliance with the law. The stipulations of the law and the opinions expressed by the members of the watchdog organization are expected to be under politicians' attack, both in act and in speech. At a more fundamental level, the meaning of a number of stability related terms that politicians use in their discourse is defined by a legal act.

\section{Political Discourse Analysis as a tool for investigating political resistance to fiscal stability}

Employing a priori reasoning may reveal some general traits of the expected political behavior under certain conditions. Starting with pinpointing the most common incentives and constraints (e.g. rules, regulations, laws, customs, commonly held values, citizens' voting habits, etc.) that a typical politician must face in his activity and using deductive logic alone, the traits of the expected political behavior could be identified. At a later stage, these assumptions are compared with observed political behavior. However, a distinctive feature of apriorism is its tenet that propositions deduced from a set of a priori categories using deductive logic cannot be proved or refuted on the basis of experience, as they are necessarily true (von Mises, 1962). More specifically, using a priori reasoning, valuable assumptions may be drawn about the expected political resistance to any institution that seeks to deter discretionary political power. As we have argued above, a certain degree of political resistance to fiscal stability institutions is to be expected in democracies.

In contrast to the aprioristic view on economics held by von Mises, supporters of mainstream economics believe that since experience is the only source of knowledge, every proposition needs empirical confirmation in order to be considered true. Expected political behavior deduced through a priori reasoning materializes in practice in different ways, depending on

\section{DE GRUYTER OPEN}


Simandan, R. (2017).

the time, place, and context. An empirical analysis of particular political positioning is needed in order to form a clearer picture on the discursive details of this political reality. We shall regard the apriorically deduced political bias against fiscal stability institutions as an intrinsic feature of present-day democracy and the investigation of the linguistic tools politicians employ in their positioning is not meant to prove or disprove it. Rather, we posit that studying discourse may reveal key information about the mindset of politicians related to this issue and, on this basis, hypotheses about the sustainability of the institutional framew ork for fiscal stability may be put forward.

Since the notion that politics and language are intrinsically related at a fundamental level is deeply embedded in the Western political thought, an alternative way of looking at political action has developed, namely the analysis of political discourse (Chilton, 2004: 4). In the most general sense, discourse denotes the practice of writing and talking (Phillips et al., 2004: 636). Through text and talk, meaningful ideas are produced and reproduced. Discourse analysis investigates how socially constructed ideas and realities such as institutions and organizations are created and preserved through talk, text, and action. Identifying and analyzing discourse has nowadays become a common concern in humanities and social sciences (Fairclough, 2003: 123). Political positioning vis-à-vis various matters of political life cannot be investigated directly - it can only be analyzed by looking at the text and talk that political actors use to communicate their views. Conversely, writing and talking about politics is closely linked with social and political behavior (Chilton and Schäffner, 2002: 5). A complex relation among discourse, text, and action emerges, relation that can be described as mutually constitutive (Phillips et al., 2004: 637). The meaning of the terms and ideas in political discourse is social meaning arising from the actions of the actors, and at the same time, discourse gives meaning to these actions, thus constituting the social world.

The consensus arising from this body of literature is that politics is both acting and talking (van Dijk, 1997: 20). In this sense, there is no contrast between speaking and doing, as is the case in popular belief. Taking political action is also accomplished trough speech (and writing). Proper use of language from the part of politicians may pave the way for the conception of a certain desired institution or for reforming the existing institutions. Many traditional political actions - such as drafting and passing laws, voting, and executive decision-making, in addition to the conventional political discourse genres like campaigning, political advertising, and propaganda - have important discursive components. Therefore, political discourse is increasingly seen as a form of political action and as a part of the political process. As a method, discourse analysis may reveal some hidden cognitions of participants to the discursive political practice, an impossible task to accomplish through traditional exploratory techniques of the political sciences. Moreover, as van Dijk argues, PDA is chiefly a critical enterprise, dealing with such realities as power, power use and power abuse through political discourse.

\section{DE GRUYTER OPEN}

Timisoara Journal of Economics and Business | ISSN: 2286-0991 | www.tjeb.ro Year 2017 | Volume 10 | Issue 1 | Pages: 104-119 
Simandan, R. (2017).

Fiscal stability in political discourse: the Romanian case

Writing about the narrative tradition in social sciences open by Max Weber, Fischer (2003: 162) argues, "Narratives create and shape social meaning by imposing a coherent interpretation on the whirl of events and actions around us". Unlike the empirical tradition in social sciences that establishes causal connections between social events, the narrative method explains social phenomena in terms of social intensions and motivation and the contribution of these factors to the ensuing social change. Thus, the narrative method, as interpretation of intensions and motivation of specific actors, study subjective forces that make things happen in the real world. Or, as Fischer (2003: 165) puts it, "A social science without [the study of subjective motivations] is an impoverished endeavour". In this view, the failure of the empirical approach to the study of social phenomena is due to its inability to take into account subjective understanding of reality. Therefore, the analysis of political discourse reveals the subjective understanding of the economic reality from the part of the decision makers.

As we have shown above, the institutional background of fiscal stability is comprised of a legal act and an organization that oversees the application of the law. The meaning of a number of terms related to fiscal stability is precisely defined in that legal act. However, in political discourse the exact meaning of the terms that politicians use may be drastically changed. In political practice, the attribution of meaning to such technical terms as fiscal stability, fiscal responsibility, fiscal transparency, fiscal predictability, economic development, etc. is dimly constrained by economic theory or legal definitions, not to mention the fact that science and legal practice themselves may be seen as social processes rather than objective methodologies. As the scholars of the discourse analysis field have long argued, a parallel reality is constructed through discourse (Fischer, 2003: 53).

Political resistance to a given institutional framework can be analyzed by looking at various actions intended to alter the features of the framework, such as violations of the legal provisions or the introduction of divergent legal amendments. However, all these actions generate text and talk, both before and after they are accomplished. Institutions are produced and reproduced through discourses. Standing against the institutions of fiscal stability, politicians contribute to the creation of a discursive practice that becomes intrinsically linked to that institution. In fact, adopting the view on institutions proposed by Phillips et al. (2004), we may even argue that the institutional framework for fiscal stability also comprises the political discourse related to it (both in favor and in opposition). An institutional analysis must comprise an analysis of discourse associated with that institution. We maintain that discourse analysis provides a consistent framework for the investigation of political resistance to the institutions that constrain fiscal discretion of politicians in power.

The fundamental linguistic mechanism of discourse is the storyline. As Hajer (1995: 56) defines it, a storylines is a type of narrative "that allows actors to draw upon various discursive categories to give meaning to specific physical or social phenomena". In this conception, the

\section{DE GRUYTER OPEN}


Simandan, R. (2017).

interpretative nature of a storyline is key to understanding its functions. To appreciate social reality, people do not habitually employ comprehensive social theories and philosophies, but rather make use of storylines as convenient collections of rules of thumb. A storyline unifies disparate elements regularly found in discourse that otherwise may have little in common and provide people with handy pieces of reasoning useful for their cognition. A particular understanding of a given social reality is advanced using a number of storylines. A discursive frame for forthcoming speakers on the same issues is thus created.

A few main storylines against fiscal stability rules have been identified in political discourse in recent years in Romania. They have been categorized into three groups of arguments under the following headings: "Budget deficit in not important if it is the outcome of large public investments", "Limitations on public expenditures do not allow us to grow" and "Reducing the government expenditures now will lead to a recession" (Şimandan, 2017). Acting as shorthand social reconstructions of reality, storylines are important in themselves, beyond the more or less rigorous economic thinking they may encompass. Consequently, in analyzing the storylines we shall not discuss the rightfulness of the underlying economic logic behind them.

Arguing that budget deficits that usually follow an increase in public spending have no longrun detrimental macroeconomic consequences if this leads to an improvement in the quality of transportation infrastructure, politicians were able to go up against a key element of fiscal stability: a low and sustainable budget deficit. In this storyline, the public investment is presented as categorically different from public expenditures. In other words, "investment is good while consumption spending is bad". Surely, the underlying reason for this severance relates to the usual definition of investment, i.e., money spent today in the expectation of some benefit in the future. Investing in infrastructure is portrayed as the essential activity of government able to stimulate economic growth. This argument is well summarized in a statement by the Prime Minister Emil Boc who said in 2009 at the inauguration ceremony of a large transport infrastructure site, "Money spent on infrastructure is not money down the drain, like it is [the case with the money spent] on large-screen TVs and fancy furniture" (Breazu, 2009).

In the storyline that makes a connection between public expenditures and economic growth prospects, politicians maintain that imposing limits on public expenditures (like the ones stipulated in the Fiscal Responsibility Law) has damaging consequences on the capacity of the economy to generate growth and development. The "they versus us" logic is usually employed, since the source of the limitative legal framework is identified as coming from outside the country. This line of reasoning has been summed up by the Finance Minister Eugen Teodorovici in 2015 when, discussing the fiscal policy of the cabinet, he rhetorically asked in an interview "Why should we be the champions of austerity when others spend and thus develop?", also adding, "If I were to choose between national interest and European

\section{DE GRUYTER OPEN}


Simandan, R. (2017).

Fiscal stability in political discourse: the Romanian case

interest, I would choose the national interest without thinking too much about it". He also suggested a more drastic strategy in negotiations with European partners on fiscal issues: "I am a pro-business minister and we must have a more daring approach" (Anghel, 2015).

Finally, in the storyline that links a decrease in public spending (aiming at reducing the budget deficit) to an increased likelihood of a recession in the future, politicians maintain that if the budget deficit target (for instance, the one specified in the fiscal responsibility law) were attained, a recession would most likely happen next. In the trouble-free logic behind this argument, the more government spends the more stimuli the economy receives. The Minister of Transport Radu Berceanu plainly warned in 2010, "Romania will not exit the recession if the IMF does not accept an increase in the budget deficit" (Ziare.com, 2010). Since the "acceptance" of an increase in the deficit is to be expected from outside of the country, this storyline is usually intertwined with the previous one.

\section{Methodology}

The main category of actors (speakers) taken into account are politicians - broadly defined to include participants in the political process, such as parliamentarians, members of the cabinet, local elected politicians and high-ranking members of political parties not holding official positions. The actions and practices of these participants in the political process are regarded as both political and discursive.

Beside politicians, we have considered the discourse of high-ranking bureaucrats 1 on fiscal stability related issues. The rationale for this choice is twofold. First, bureaucrats' discourse often has a political function. The agencies that employ the bureaucrats are usually organizations of power: the relations between these agencies and ordinary citizens are characterized by a high degree of power of the agencies over the citizens. Second, if successful, the discourse has political implications as well. As the scholars from the public choice school have shown, the relation between politicians and bureaucrats is complicated by the fact that politicians usually lack incentives and resources to closely monitor the activity of bureaus, thus bureau chiefs are in a position where they enjoy a great deal of power (Niskanen, 1994: 272). In addition, having highly specialized knowledge on specific markets makes bureaucrats suitable to act as advisors for politicians. Consequently, public discourse of high-ranking bureaucrats (such as officials from the central bank or different regulation

${ }^{1}$ In the economic theory of the public sector inspired by the public choice field, the term bureaucrat has a precise meaning, free from any deprecatory connotation. A synonym for public servant from the classical public finance literature, it designates any person who works in a bureau and is appointed by elected politicians. The main characteristic of a bureau is the fact that it is a nonprofit organization that is financed by a periodic appropriation or grant, usually from the central or local public budget (Niskanen, 1994; Şimandan, 2009).

DE GRUYTER OPEN
Timisoara Journal of Economics and Business | ISSN: 2286-0991 | www.tjeb.ro Year 2017 | Volume 10 | Issue 1 | Pages: 104-119 
Simandan, R. (2017).

Fiscal stability in political discourse: the Romanian case

agencies) is well suited to become the object of analysis with the tools provided by the PDA field.

The unit of analysis in our empirical analysis is the statement. Statements are spoken or written sentences expressed by an actor reported by the media - i.e., any sequence of words that is regarded as capable of standing alone to express a coherent thought. The statement must be recognized both as political and as relevant. Political statements are statements made in a political context. Events such as cabinet meetings, parliamentary sessions, press conferences, political rallies, TV and radio shows and improvised hallway declarations reported by the media have been considered as embodying political contexts. Relevant statements are considered those expressing doubt or opposition to institutions of fiscal stability, such as the established targets for budget deficit and public expenditure, the relevance of the legal fiscal rules (as defined in article 6 of the FRL), and the content of opinions and recommendations issued by the FC. As detailed above, actors taken into account are politicians and high-ranking bureaucrats.

Statements have been selected from the online archives of three most prestigious press agencies: Agerpres (http://www.agerpres.ro/), Mediafax (http://www.mediafax.ro/), and România Actualități (http://romania-actualitati.ro/). In addition, online archives of the following news and debate platforms have been used: Hotnews (http://www.hotnews.ro/), Ziarul Financiar (http://www.zf.ro/), and Ziare.com (http://www.ziare.com/). Taken together, these sources offer a reliable starting place for building an image of the Romanian political discourse. The database of news articles has been compiled following an online search using the terms listed in Table 1.

Table 1. Searchwords

\begin{tabular}{cccc}
\hline \multicolumn{2}{c}{ Searchwords related to fiscal stability } & \multicolumn{2}{c}{ Searchwords related to the main storylines } \\
\hline Romanian term(s) & English translation & Romanian term(s) & English translation \\
\hline deficit bugetar & budget deficit & investiții publice & public investment \\
\hline excedent/surplus bugetar & budget surplus & infrastructură & infrastructure \\
\hline cheltuieli bugetare & government expenditure & interes național & national interest \\
\hline cheltuieli publice & public expenditure & dezvoltare/dezvoltăm & development/to develop \\
\hline venituri bugetare & government revenue & creştere/creştem & growth/to grow \\
\hline regulă (reguli) fiscală (fiscale) & fiscal rule/s & străini & foreigners \\
\hline stabilitate/instabilitate fiscală & fiscal stability/instability & recesiune & recession \\
\hline consiliu(I) fiscal & fiscal council & & \\
\hline
\end{tabular}

Source: own

These terms relate to the main storylines identified as being constitutive to the political discourse against fiscal stability institutions (Şimandan, 2017). Deciding over these terms and reviewing the use of storylines in the media embody the exploitative pretest stage of our

\section{DE GRUYTER OPEN}


Simandan, R. (2017).

empirical analysis. Each term (phrase) related to fiscal stability issues has been joined with each term (phrase) related to the main storylines and all the elements from the resulting matrix have been used as searchwords in the archive of the press agencies mentioned above. All news articles have been investigated trough a content analysis. In one article, the employment of more than one storyline could be identified. The article has been awarded to one or more predetermined storylines. An article has been attributed to "other storylines" if it showed a political disagreement with the opinions and recommendations issued by the FC in different terms than those related to the main storylines. The variable "actor" (or "speaker") has been identified as either "politician" or "bureaucrat". Only opinions expressed by the speakers (either directly or indirectly reported) have been taken into account, not opinions expressed by the media themselves. Our analysis covered the period from 2007 up to date.

\section{Results and discussion}

Our empirical analysis of the discursive practice against established fiscal stability institutions shows that politicians and high-ranking bureaucrats rely on few storylines in their public statements. There have been 94 occurrences of the three storylines outlined above. The employment of different storylines has been rather weak - only ten occurrences over the analyzed period.

Figure 2 presents the number of times a specific storyline has been addressed in political discourse between 2007 and 2015. The first important result is that publically revealed political disagreement towards established fiscal stability institutions intensified in recent years. In addition, the reliance on storylines has drastically amplified in public debate. Key terms related to important storylines have been increasingly invoked. A second key result is that the storyline that tries to trivialize the significance of budget deficit if it results from large public spending on (transport) infrastructure has been the most widely used storyline. The use of this storyline increased from one occurrence in 2008 to nine occurrences in 2015. This dramatic increase in the use of storylines in expressing disagreement with fiscal stability rules seen in 2015 compared to previous years can be attributed to a conjunctural event: the 2015 - 2016 tax cut program put in practice by the government and the ensuing public debate on the perceived threat to fiscal stability posed by this program (Şimandan, 2017). 
Simandan, R. (2017).

Fiscal stability in political discourse: the Romanian case

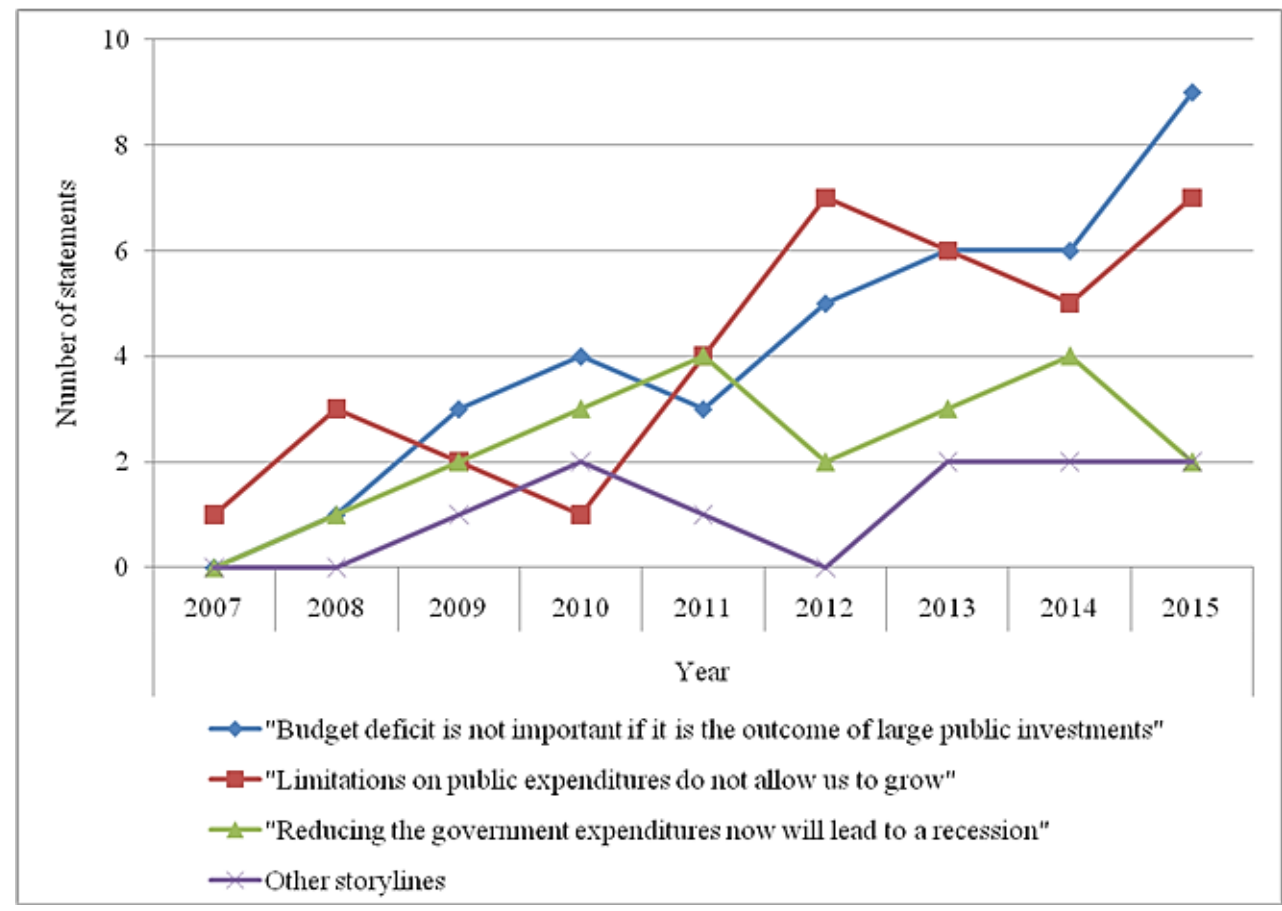

Figure 2. The use of main storylines in political discourse over time

Source: own.

A last unsurprising result is that public servants do not engage in public communication against fiscal stability institutions as much as politicians do. Table 2 shows the number of times that politicians and bureaucrats engaged in public disagreements with fiscal stability rules relying on identifiable storylines.

Table 2. Number of times that a speaker addressed a specific storyline

\begin{tabular}{cccc}
\hline Storyline $\backslash$ Actor & Politician & Bureaucrat & $\sum$ \\
\hline "Budget deficit in not important if it is the outcome of large public investments" & 33 & 4 & 37 \\
\hline "Limitations on public expenditures do not allow us to grow" & 33 & 3 & 36 \\
\hline "Reducing the government expenditures now will lead to a recession" & 19 & 2 & 21 \\
\hline Other storylines & 8 & 2 & 10 \\
\hline$\sum$ & 93 & 11 & 104 \\
\hline
\end{tabular}

Source: own

Timisoara Journal of Economics and Business | ISSN: 2286-0991 | www.tjeb.ro

Year 2017 | Volume 10 | Issue 1 | Pages: 104-119 
Simandan, R. (2017).

\section{Conclusions}

This article has proposed political discourse analysis as a theoretical framework for the analysis of political resistance to fiscal stability institutions. We argued that alongside conventional policy analysis based on economics and political sciences, PDA has the potential of revealing the mindset of politicians and public officials pertaining to fiscal stability issues. On this basis, the sustainability of these institutions can be more accurately assessed. Given the bias of the democratic political process toward deficit spending and public debt, a comprehensive framework for upholding fiscal stability has been put in place in all advanced economies. Further, recognizing the challenges to its sustainability posed by the political process, this framework has been endowed with protection against political interference. We find that publicly expressed disagreement with established fiscal stability institutions from the part of politicians and high-ranking bureaucrats has drastically increased over the analyzed period. The research has also revealed that the most employed storyline has been the one that belittles the significance of fiscal stability if the state uses the fiscal revenues for investing in transport infrastructure.

\section{References}

Anghel, I. (2015). De ce să fim noi campioni la austeritate când alţii cheltuiesc şi astfel se dezvoltă? [Why should we be the champions of austerity while others spend and thus develop?], Ziarul financiar, 21 July. Retrieved from http://www.zf.ro/eveniment/interviu-cu-ministrul-finantelor-eugen-teodorovicide-ce-sa-fim-noi-campioni-la-austeritate-cand-altii-cheltuiesc-si-astfel-se-dezvolta14618566 [accessed 24 April 2016].

Breazu, M. (2009). Boc va cere majorarea deficitului bugetar [Boc to ask for budget deficit increase]. Radio Romania Actualităţi, 6 July. Retrieved from http://romaniaactualitati.ro/boc_va_cere_majorarea_deficitului_bugetar-2050 [accessed 24 April 2016].

Brennan, G., \& Buchanan, J. M. (1980). The power to tax: analytic foundations of a fiscal constitution. Cambridge: Cambridge University Press.

Buchanan, J. M., \& Tullock, G. (1962). The calculus of consent. Logical foundations of constitutional democracy (Vol. 3). Ann Arbor: University of Michigan Press.

Buchanan, J. M., \& Wagner, R. E. (1977). Democracy in deficit: the political legacy of Lord Keynes. New York: Academic Press.

Calmfors, L., \& Wren-Lewis, S. (2011). What should fiscal councils do? CESifo Working Paper, no. 3382 .

Chilton, P. (2004). Analysing political discourse: theory and practice. London: Routledge.

Chilton, P., \& Schäffner, C. (2002). Introduction. Themes and principles in the analysis of political discourse. In P. Chilton \& C. Schäffner (Eds.), Politics as text and talk: analytic approaches to political discourse (pp. 1-41). Amsterdam: John Benjamins Publishing.

Fairclough, N. (2003). Analysing discourse: textual analysis for social research. London: Psychology Press.

DE GRUYTER OPEN
Timisoara Journal of Economics and Business | ISSN: 2286-0991 | www.tjeb.ro Year 2017 | Volume 10 | Issue 1 | Pages: 104-119 
Simandan, R. (2017).

Fiscal stability in political discourse: the Romanian case

Fischer, F. (2003). Reframing public policy: discursive politics and deliberative practices. Oxford University Press.

Gunning, J. P. (2003). Understanding democracy. An introduction to public choice. Taiwan: Nomad Press.

Gwartney, J. D., Stroup, R. L., \& Sobel, R. S. (2008). Macroeconomics: private and public choice, 13th Edition, Mason, OH: South-Western, Cengage Learning.

Hajer, M. (1995). The politics of environmental discourse. Ecological modernization and the policy. Oxford: Oxford University Press.

IREF (2012). Taxation in Europe. The yearly report on the evolution of European tax systems. Edited by Pierre Garello.

Law, (2010). Legea responsabilităţii fiscale nr. 69 [Fiscal responsibility law]. Retrieved from https://static.anaf.ro/static/10/Anaf/legislatie/L_69_2010R.pdf [accessed 12 May 2016].

Niskanen, W. (1994). Bureaucracy and public economics. Brookfield, Vt.: Edward Elgar.

North, D. (1990). Institutions, institutional change and economic performance. Cambridge: Cambridge University Press.

Phillips, N., Lawrence, T. B., \& Hardy, C. (2004). Discourse and institutions. Academy of Management Review, 29(4), 635-652. DOI: 10.5465/AMR.2004.14497617.

Sargent, T. J., \& Wallace, N. (1981). Some unpleasant monetarist arithmetic. FRB Minneapolis Quarterly Review, 8, 1-17.

Şimandan, R. (2017). Political resistance to fiscal stability institutions: the case of Romania. New Trends and Issues Proceedings on Humanities and Social Sciences. [Online]. 04, pp 219228. Retrieved from http://sproc.org/ojs/index.php/pntsbs/article/view/1572/1641.

Şimandan, R. (2009). Thinking about bureaucracy: Mises versus Niskanen, Romanian Economic Journal, 4(34), 85-96.

van Dijk, T. A. (1997). What is political discourse analysis? Belgian Journal of Linguistics, 11(1), 11-52. DOI: 10.1075/bjl.11.03dij.

van Dijk, T. A. (2008). Discourse and context. A sociocognitive approach. Cambridge: Cambridge University Press.

von Mises, L. (1962). The ultimate foundation of economic science. An essay on method. Princeton, New Jersey: van Nostrand.

Ziare.com (2010). Berceanu: România nu iese din recesiune dacă FMI nu acceptă creșterea deficitului [Berceanu: Romania will not exit the recession if the IMF does not accept an increase in the budget deficit], 3 May. Retrieved from http://www.ziare.com/ economie/recesiune/berceanu-romania-nu-iese-din-recesiune-daca-fmi-nu-cceptacresterea-deficitului-1013206 [accessed 24 April 2016]. 